\title{
PERLAKUAN BIOPRIMING KOMBINASI EKSTRAK TOMAT DAN Trichoderma spp. TERHADAP VIABILITAS DAN VIGOR BENIH TERUNG (Solanum melongena L.) KADALUARSA \\ Biopriming Treatment Combination of Tomato Extract and Trichoderma spp. to
} Viability and Vigor of Expired Eggplant Seeds

\author{
Saidina Ramadhani ${ }^{1}$, Trisda Kurniawan ${ }^{1}$ dan M. Abduh Ulim ${ }^{1 *}$ \\ ${ }^{1}$ Program Studi Agroteknologi, Fakultas Pertanian, Universitas Syiah Kuala
}

\begin{abstract}
Abstrak. Penelitian tentang pengaruh perlakuan biopriming terhadap viabilitas dan vigor benih terung kadaluarsa dilaksanakan di Laboratorium Ilmu dan Teknologi Benih dan Laboratorium Penyakit Tanaman Universitas Syiah Kuala, Banda Aceh pada bulan Agustus sampai dengan Oktober 2017. Penelitian ini bertujuan untuk mengetahui pengaruh konsentrasi ekstrak buah tomat dan spesies Trichoderma spp. serta interaksi antara konsentrasi ekstrak buah tomat dan spesies Trichoderma spp. terhadap viabilitras dan vigor benih terung kadaluarsa. Penelitian ini dilakukan dengan menggunakan Rancangan Acak Kelompok (RAL) pola faktorial dengan 2 faktor dan 3 ulangan. Faktor pertama yaitu konsentrasi ekstrak buah tomat yang terdiri atas 4 taraf dan faktor kedua yaitu spesies Trichoderma spp. yang terdiri atas 3 taraf. Hasil penelitian menunjukkan bahwa konsentrasi ekstrak buah tomat terbaik dijumpai pada konsentrasi ekstrak buah tomat 10\%, baik yang dikombinasikan dengan $T$. harzianum maupun $T$. asperellum. Jenis Trichoderma spp. terbaik dijumpai pada $T$. harzianum pada semua konsentrasi ekstrak buah tomat.
\end{abstract}

Kata kunci: Biopriming, Ekstrak Buah Tomat, Trichoderma spp..

\begin{abstract}
Research on the effect of biopriming treatment on viability and vigor of expired eggplant seeds was conducted at the Laboratory of Seed Science and Technology and Plant Disease Laboratory of Syiah Kuala University, Banda Aceh from August to October 2017. This study aims to determine the effect of tomato extract concentration and species Trichoderma spp. as well as the interaction between the concentration of tomato extract and species Trichoderma spp. to viability and vigor of expired eggplant seeds. This research was conducted by using Randomized Block Design (RBD) factorial pattern with 2 factors and 3 replications. The first factor is the concentration of tomato extract consisting of 4 levels and the second factor is species Trichoderma spp. which consists of 3 levels. The results showed that the best concentration of tomato extract was found in the concentration of $10 \%$ tomato extract, both combined with T. harzianum and T. asperellum. The best species of Trichoderma spp. found in T. harzianum in all concentrations of tomato extracts.
\end{abstract}

Keywords : Biopriming, Tomato Extract, Trichoderma spp..

\section{PENDAHULUAN}

Terung (Solanum melongena L.) merupakan salah satu sayuran buah yang sangat digemari masyarakat Indonesia. Hasil panen utama dari tanaman ini adalah buahnya. Dengan cita rasa yang enak, masyarakat menjadikan terung sebagai bahan sayuran dan lalapan. Terung mengandung banyak nilai gizi. Setiap $100 \mathrm{~g}$ bahan mentah terung mengandung 26 kalori, $1 \mathrm{~g}$ protein, 0,2 $\mathrm{g}$ hidrat arang, $25 \mathrm{IU}$ vitamin A, 0,04 g vitamin B dan $5 \mathrm{~g}$ vitamin $\mathrm{C}$. Selain itu, terung juga mempunyai khasiat sebagai obat karena mengandung alkaloid, solanin dan solasodin (Sunarjono, 2013).

Produktivitas terung di Indonesia terus mengalami peningkatan setiap tahunnya. Pada tahun 2011 produksi terung mencapai 9,95 ton/ha, pada tahun 2012 mencapai 10,26 ton/ha, pada tahun 2013 mencapai 10,76 ton/ha, pada tahun 2014 mencapai 10,95 ton ha $^{-1}$ dan pada tahun 2015 mencapai 11,20 ton/ha. Meskipun produktivitas terung nasional terus meningkat 
setiap tahunnya akan tetapi Indonesia hanya menyumbang $1 \%$ dari kebutuhan dunia (Badan Pusat Statistika dan Direktorat Jendral Hortikultura, 2016).

Salah satu faktor yang menjadi penyebab rendahnya produktivitas terung adalah rendahnya mutu benih yang digunakan oleh petani. Benih menjadi salah satu faktor penentu keberhasilan dalam budidaya pertanian. Sebagai bahan perbanyakan tanaman, benih harus memiliki mutu yang tinggi mencakup mutu genetik, fisik, fisiologis dan patologis agar dapat menghasilkan tanaman dengan produksi yang tinggi (Sutopo, 2002).

Benih merupakan organisme hidup yang akan mengalami kemunduran dan akhirnya mati. Penurunan viabilitas dan vigor benih akibat terjadinya kemunduran berdampak pada buruknya pertumbuhan dan penurunan produksi tanaman di lapangan. Untuk mengurangi dampak buruk dari kemunduran benih maka dilakukan teknik invigorasi benih, salah satunya yaitu dengan melakukan priming. Perlakuan priming bertujuan untuk mengendalikan laju kebutuhan air benih selama perkecambahan menggunakan larutan yang memiliki potensial osmotik rendah. Dalam proses priming juga dapat ditambahkan bahan-bahan organik yang berasal dari ekstrak buah-buahan.

Bahan organik yang digunakan dalam penelitian ini bersumber dari ekstrak buah tomat. Penggunaan ekstrak buah tomat dalam proses priming diketahui dapat meningkatkan nilai potensi tumbuh, daya berkecambah, kecepatan tumbuh dan keserempakan tumbuh. Hal ini disebabkan karena terdapat berbagai kandungan senyawa organik di dalam ekstrak buah tomat seperti karbohidrat, asam amino dan hormon tumbuh seperti Indole Acetic Acid (IAA), 2,4-D dan Indole Butyric Acid (IBA) (Marliah et al., 2010). Hasil penelitian Marliah et al. (2010), menunjukkan bahwa benih semangka kadaluarsa yang diinkubasi dengan ekstrak tomat masak dengan konsentrasi $15 \%$ selama 24 jam mampu meningkatkan nilai vigor dan viabilitas benih.

Invigorasi benih juga dapat diintegrasikan dengan Trichoderma spp. yang kemudian disebut biopriming. Biopriming adalah kegiatan invigorasi benih dengan memanfaatkan agensia hayati yang dapat memacu pertumbuhan tanaman (Bjorkman et al., 1999). Trichoderma spp. merupakan salah satu mikroba tanah yang diketahui dapat memacu pertumbuhan tanaman. Hasil penelitian Marliah et al. (2010), menunjukkan bahwa perlakuan pra perkecambahan menggunakan air kelapa muda konsentrasi $15 \%$ yang dikombinasikan dengan spesies $T$. harzianum dan T. asperellum pada konsentrasi 1 × $10^{5}$ spora $\mathrm{mL}^{-1}$ secara efektif mampu meningkatkan viabilitas dan vigor benih cabai kadaluarsa.

Berdasarkan uraian diatas, maka perlu dilakukan kajian lebih lanjut apakah biopriming kombinasi ekstrak tomat dan Trichoderma spp. dapat meningkatkan viabilitas dan vigor benih terung kadaluarsa.

\section{METODE PENELITIAN}

\section{Tempat dan Waktu Penelitian}

Penelitian ini dilaksanakan di Kebun Percobaan, Penelitian dilaksanakan di Laboratorium Ilmu dan Teknologi Benih Program Studi Agroteknologi dan Laboratorium Penyakit Tanaman Program Studi Proteksi Tanaman, Banda Aceh yang dimulai pada bulan Agustus hingga Oktober 2017.

\section{Alat dan Bahan Penelitian}

Alat-alat yang digunakan dalam penelitian ini gelas ukur, erlenmeyer, cawan petri, autoclave, mikroskop, haemacytometer, scalpel, pinset, blender, oven, mixer, aerator, Laminar Air Flow Cabinet (LAFC), desikator, saringan, corong plastik, tray plastik ukuran 34 x $25 \times 4,5 \mathrm{~cm}$, timbangan analitik dan alat tulis. Bahan-bahan yang digunakan dalam 
penelitian ini adalah benih terung varietas Bungo F1 kadaluarsa sebanyak 925 butir, $1 \mathrm{~kg}$ buah tomat Aceh, T. harzianum, T. asperellum, akuades, Potato Dextrose Agar (PDA), campuran tanah dan kompos (1:1), karet, plastik anti panas, tisu, kertas merang dan kertas label.

\section{Rancangan Penelitian}

Penelitian ini dilakukan dengan menggunakan Rancangan Acak Lengkap (RAL) pola Faktorial dengan 2 faktor dan 3 ulangan. Faktor pertama yaitu konsentrasi ekstrak buah tomat (K) yang terdiri dari 4 taraf yaitu: $\mathrm{K}_{0}=\mathrm{Kontrol}$ (akuades) $; \mathrm{K}_{1}=$ Konsentrasi ekstrak tomat $10 \% ; \mathrm{K}_{2}=$ Konsentrasi ekstrak tomat $15 \% ; \mathrm{K}_{3}=$ Konsentrasi ekstrak tomat $20 \%$. Faktor kedua adalah spesies Trichoderma spp. yang terdiri dari 3 taraf yaitu: $\mathrm{T}_{0}=$ Tanpa Trichoderma spp.; $\mathrm{T}_{1}=$ Benih diinkubasi dengan T. Harzianum; $\mathrm{T}_{2}=$ Benih diinkubasi dengan T. asperellum. Sehingga diperoleh 12 kombinasi perlakuan dan 36 unit percobaan. Susunan perlakuan dapat dilihat pada Tabel 1.

Tabel 1. Susunan Kombinasi Perlakuan Konsentrasi Ekstrak Buah Tomat (K) dan Spesies Trichoderma spp. (T)

\begin{tabular}{cccc}
\hline No. & Kombinasi Perlakuan & $\begin{array}{c}\text { Konsentrasi Ekstrak Buah } \\
\text { Tomat }(\%)\end{array}$ & Spesies Trichoderma spp. \\
\hline 1. & $\mathrm{~K}_{0} \mathrm{~T}_{0}$ & 0 & Tanpa Trichoderma $\mathrm{spp}$. \\
2. & $\mathrm{~K}_{1} \mathrm{~T}_{0}$ & 10 & Tanpa Trichoderma $\mathrm{spp}$. \\
3. & $\mathrm{~K}_{2} \mathrm{~T}_{0}$ & 15 & Tanpa Trichoderma $\mathrm{spp}$. \\
4. & $\mathrm{~K}_{3} \mathrm{~T}_{0}$ & 20 & Tanpa Trichoderma $\mathrm{spp}$. \\
5. & $\mathrm{~K}_{0} \mathrm{~T}_{1}$ & 0 & T. harzianum \\
6. & $\mathrm{~K}_{1} \mathrm{~T}_{1}$ & 10 & T. harzianum \\
7. & $\mathrm{~K}_{2} \mathrm{~T}_{1}$ & 15 & T. harzianum \\
8. & $\mathrm{~K}_{3} \mathrm{~T}_{1}$ & 20 & T. harzianum \\
9. & $\mathrm{~K}_{0} \mathrm{~T}_{2}$ & 0 & T. asperellum \\
10. & $\mathrm{~K}_{1} \mathrm{~T}_{2}$ & 10 & T. asperellum \\
11. & $\mathrm{~K}_{2} \mathrm{~T}_{2}$ & 15 & T. asperellum \\
12. & $\mathrm{~K}_{3} \mathrm{~T}_{2}$ & 20 & T. asperellum \\
\hline
\end{tabular}

Keterangan: $\mathrm{K}=$ Konsentrasi Ekstrak Buah Tomat; $\mathrm{T}=$ Trichoderma spp.

\section{Pelaksanaan Penelitian}

\section{Persiapan Benih}

Benih yang digunakan adalah benih yang sudah mengalami kemunduran, namun tidak mengalami kerusakan secara fisik. Uji pendahuluan dilakukan terlebih dahulu untuk mengetahui viabilitas awal benih dan diperoleh nilai daya berkecambah benih sebesar $56 \%$.

\section{Persiapan Ekstrak Buah Tomat}

Buah tomat terlebih dahulu dicuci dengan air bersih agar tidak ada kotoran yang menempel. Buah tomat kemudian dibelah dan dipisahkan dari bijinya, kemudian dihaluskan menggunakan blender tanpa dicampur air. Buah tomat yang sudah halus disaring sehingga didapatkan ekstrak buah tomat yang murni.

\section{Persiapan Trichoderma}

Trichoderma yang digunakan pada perlakuan invigorasi terdiri dari dua jenis yaitu $T$. Harzianum yang diisolasi dari perakaran tanaman kopi dan $T$. Asperellum yang diisolasi dari perakaran tanaman bambu. Trichoderma dikembangkan pada media Potato Dextrose Agar (PDA) selama 2 minggu hingga terbentuk spora, proses ini dilakukan di LAFC. Setelah 2 
minggu, dilakukan pengambilan miselia jamur beserta konidia untuk selanjutnya dilakukan pengenceran. Konsentrasi spora yang digunakan adalah $1 \times 10^{5}$ spora $\mathrm{mL}^{-1}$.

\section{Perlakuan Biopriming}

Benih dimasukkan ke dalam botol yang sudah berisi campuran ekstrak buah tomat dan akuades pada masing-masing konsentrasi (0\%, 10\%, 15\% dan 20\%). Inkubasi dilakukan selama 1 x 24 jam. Ketersediaan oksigen di dalam larutan dijaga dengan menggunakan aerator. Benih kemudian dicuci dengan akuades dan kadar air benih diturunkan menggunakan desikator. Setelah kadar air kembali seperti semula, benih diinkubasi dalam suspensi Trichoderma spp. selama 24 jam, kemudian dilakukan uji perkecambahan.

\section{Uji Perkecambahan}

Uji perkecambahan benih terung dilakukan menggunakan media campuran tanah dan kompos dengan perbandingan 1:1. Tanah dan kompos sebelum digunakan terlebih dahulu disterilisasi menggunakan autoclave pada suhu $121{ }^{\circ} \mathrm{C}$ selama 30 menit. Wadah perkecambahan yang digunakan adalah tray plastik dan masing-masing perlakuan diberi label.

\section{Peubah yang diamati}

\section{Potensi Tumbuh Maksimum (PTM)}

Potensi Tumbuh Maksimum (PTM) diamati berdasarkan jumlah benih yang menunjukkan gejala pertumbuhan pada hari terakhir (14 HST) dan dinyatakan dalam persen (\%). Potensi tumbuh maksimum dinyatakan dengan persen $(\%)$ dan dihitung dengan rumus:

$$
\operatorname{PTM}(\%)=\frac{\sum \text { benih yang menunjukkan gejala tumbuh }}{\sum \text { benih yang diuji }} \times 100 \%
$$

\section{Daya Berkecambah (DB)}

Daya Berkecambah (DB) diamati berdasarkan jumlah kecambah normal pada pengamatan pertama (7 HST) dan kedua (14 HST) serta dinyatakan dalam persen (\%). DB dinyatakan dalam persen $(\%)$ dan dihitung dengan rumus:

$$
\mathrm{DB}(\%)=\frac{\sum \mathrm{KN} \text { pengamatan } \mathrm{I}+\sum \mathrm{KN} \text { pengamatan II }}{\sum \text { Benih yang diuji }} \times 100
$$

\section{Indeks Vigor (IV)}

Indeks vigor (IV) diamati berdasarkan penampilan kecambah yang tumbuh kuat pada pengamatan pertama (7 HST). Indeks vigor dinyatakan dalam persen (\%) dan dihitung dengan menggunakan rumus:

$$
\text { IV }(\%)=\frac{\sum \text { Kecambah normal kuat pengamatan I }}{\sum \text { benih yang diuji }}
$$

\section{Keserempakan Tumbuh $\left(\mathrm{K}_{\mathrm{ST}}\right)$}

Keserempakan Tumbuh $\left(\mathrm{K}_{\mathrm{ST}}\right)$ diperoleh dengan menghitung jumlah kecambah normal diantara pengamatan pertama (7 HST) dan kedua (14 HST) yaitu pada 10 HST dan dinyatakan dalam persen. Rumus yang digunakan dalam pengamatan ini adalah:

$$
\mathrm{K}_{\mathrm{ST}}(\%)=\frac{\sum \text { Kecambah Normal pada hari ke } 10}{\sum \text { Benih yang diuji }} \times 100 \%
$$




\section{Kecepatan Tumbuh $\left(K_{\mathrm{CT}}\right)$}

Kecepatan Tumbuh $\left(\mathrm{K}_{\mathrm{CT}}\right)$ diamati setiap hari mulai hari pertama sampai hari ke-14 setelah tanam. Kecepatan tumbuh dinyatakan dalam persen per etmal, dan dihitung dengan rumus:

Keterangan:

$$
\mathrm{K}_{\mathrm{CT}}(\% / \text { etmal })=\frac{\mathrm{N} 1}{\mathrm{~W} 1}+\frac{\mathrm{N} 2}{\mathrm{~W} 2}+\ldots+\frac{\mathrm{Nn}}{\mathrm{Wn}}
$$

$\mathrm{K}_{\mathrm{CT}} \quad=$ Kecepatan tumbuh (\%/etmal)

N1-Nn $=$ Bertambahnya jumlah kecambah normal pada waktu n $1,2, \ldots$ n hari setelah tanam $(\%)$

$\mathrm{W} 1-\mathrm{W}_{2}=$ Jumlah waktu dari saat tanam sampai dengan saat pengamatan ke $1,2, \ldots \mathrm{n}$ (etmal).

\section{Waktu yang dibutuhkan Untuk Mencapai 50\% Kecambah Normal $\left(\mathbf{T}_{50}\right)$}

Nilai $\mathrm{T}_{50}$ diamati berdasarkan waktu yang diperlukan untuk mencapai jumlah benih yang berkecambah normal setiap hari hingga 50\% dari total perkecambahan relatif, dan dinyatakan dalam satuan hari. Pengamatan dilakukan setiap hari selama 14 hari. Rumus untuk menghitung nilai $\mathrm{T}_{50}$ sebagai berikut:

Keterangan:

$$
\mathrm{T} 50 \text { (hari) }=\mathrm{ti}+\frac{(\mathrm{n} 50 \%-\mathrm{ni})}{(\mathrm{nj}-\mathrm{ni})}(\mathrm{tj}-\mathrm{ni})
$$

ti $\quad=$ Waktu (hari) batas bawah sebelum mencapai $50 \%$ perkecambahan

n $50 \%=$ Jumlah benih berkecambah (50\% dari total benih yang berkecambah)

$\mathrm{nj} \quad=$ Jumlah kecambah batas atas setelah mencapai $50 \%$ total perkecambahan

$\mathrm{tj} \quad=$ Waktu (hari) batas atas setelah mencapai $50 \%$ perkecambahan

ni = Jumlah kecambah batas bawah sebelum mencapai $50 \%$ total perkecambahan.

\section{HASIL DAN PEMBAHASAN}

Pengaruh Perlakuan Biopriming Kombinasi Ekstrak Buah Tomat dan Trichoderma spp. terhadap Tolok Ukur Viabilitas dan Vigor Benih Terung (Solanum melongena L.) Kadaluarsa

Berdasarkan uji $\mathrm{F}$ pengaruh perlakuan benih menggunakan konsentrasi ekstrak buah tomat, spesies Trichoderma spp. serta interaksi antara perlakuan konsentrasi ekstrak buah tomat dan spesies Trichoderma spp. terhadap data pengamatan berbagai tolok ukur viabilitas dan vigor benih terung kadaluarsa dapat dilihat pada Tabel 2 .

Tabel 2. Nilai Rerata Uji F Pengaruh Perlakuan Biopriming Kombinasi Ekstrak Buah Tomat dan Trichoderma spp. terhadap Tolok Ukur Viabilitas dan Vigor Benih Terung Kadaluarsa

\begin{tabular}{lcccc}
\hline \multirow{2}{*}{ Tolok Ukur } & \multicolumn{3}{c}{ Perlakuan } & \multirow{2}{*}{ KK (\%) } \\
\cline { 2 - 4 } & $\mathrm{K}$ & $\mathrm{T}$ & $\mathrm{K} \mathrm{x} \mathrm{T}$ & \\
\hline Potensi Tumbuh Maksimum (\%) & $0,10^{\mathrm{tn}}$ & $10,84^{* *}$ & $2,54^{*}$ & 12,26 \\
Daya Berkecambah (\%) & $0,21^{\text {tn }}$ & $14,25^{* *}$ & $1,68^{\text {tn }}$ & 12,09 \\
Indeks Vigor (\%) & $7,53^{* *}$ & $102,95^{* *}$ & $11,76^{* *}$ & 11,31 \\
Keserempakan Tumbuh (\%) & $1,82^{\text {tn }}$ & $43,11^{* *}$ & $3,33^{*}$ & 12,10 \\
Kecepatan Tumbuh (\%) & $2,37^{\text {tn }}$ & $38,29^{* *}$ & $4,77^{* *}$ & 8,25 \\
Lama Waktu yang Dibutuhkan untuk & & & & \\
Mencapai 50\% Perkecambahan Normal & $4,54^{*}$ & $12,24^{* *}$ & $8,04^{* *}$ & 14,32 \\
Relatif (hari) & & & & \\
\hline
\end{tabular}


Keterangan : *: Berpengaruh Nyata; **: Berpengaruh Sangat Nyata; Tn: Tidak Berpengaruh Nyata; K: Konsentrasi Ekstrak Buah Tomat (\%); T: Spesies Trichoderma; KxT: Interaksi antara Konsentrasi Ekstrak Buah Tomat (\%) dan Spesies Trichoderma; KK: Koefisien Keragaman (\%).

Tabel 2 menunjukkan bahwa terjadi interaksi yang sangat nyata antara konsentrasi ekstrak buah tomat dengan spesies Trichoderma spp. pada peubah indeks vigor, kecepatan tumbuh, lama waktu yang dibutuhkan untuk mencapai 50\% perkecambahan normal relatif dan nyata pada peubah potensi tumbuh maksimum dan keserempakan tumbuh. Tidak terjadi interaksi yang nyata pada peubah daya berkecambah, namun perlakuan jenis Trichoderma spp. berpengaruh sangat nyata.

\section{Interaksi antara Ekstrak Buah Tomat dan Trichoderma spp. terhadap Viabilitas dan Vigor Benih Terung Kadaluarsa}

\section{a. Potensi Tumbuh Maksimum (\%)}

Rata-rata nilai potensi tumbuh maksimum (PTM) benih terung kadaluarsa akibat interaksi antara konsentrasi ekstrak buah tomat dan spesies Trichoderma spp. dapat dilihat pada Tabel 3.

Tabel 3. Rata-Rata Nilai Potensi Tumbuh Maksimum (\%) Benih Terung Kadaluarsa akibat Interaksi antara Konsentrasi Ekstrak Buah Tomat dan Spesies Trichoderma spp.

\begin{tabular}{cccc}
\hline \multirow{2}{*}{$\begin{array}{c}\text { Konsentrasi Ekstrak Buah } \\
\text { Tomat }\end{array}$} & \multicolumn{3}{c}{ Spesies Trichoderma spp. } \\
\cline { 2 - 4 } & Tanpa Trichoderma & Trichoderma & Trichoderma \\
harzianum $\left(\mathrm{T}_{1}\right)$ & asperellum $\left(\mathrm{T}_{2}\right)$ \\
\hline \multirow{2}{*}{$0 \%\left(\mathrm{~K}_{0}\right)$} & 58,67 & 65,33 & 66,67 \\
& $(50,01) \mathrm{abc}$ & $(54,08) \mathrm{bcd}$ & $(55,55) \mathrm{bcd}$ \\
$10 \%\left(\mathrm{~K}_{1}\right)$ & 50,67 & 81,33 & 56,00 \\
& $(45,38) \mathrm{ab}$ & $(65,73) \mathrm{d}$ & $(48,52) \mathrm{abc}$ \\
$15 \%\left(\mathrm{~K}_{2}\right)$ & 42,67 & 78,67 & 65,33 \\
& $(40,78) \mathrm{a}$ & $(62,51) \mathrm{d}$ & $(53,98) \mathrm{bcd}$ \\
$20 \%\left(\mathrm{~K}_{3}\right)$ & 66,67 & 70,67 & 58,67 \\
& $(54,79) \mathrm{bcd}$ & $(57,58) \mathrm{cd}$ & $(50.05) \mathrm{abc}$ \\
\hline
\end{tabular}

Keterangan : -Angka yang Diikuti oleh Huruf yang Sama Berbeda Tidak Nyata pada Taraf 0,05 (Uji DMRT) -() Data setelah Ditransformasi

\section{b. Indeks Vigor (\%)}

Rerata nilai indeks vigor (IV) benih terung kadaluarsa akibat interaksi antara konsentrasi ekstrak buah tomat dan spesies Trichoderma spp. dapat dilihat pada Tabel 4.

Tabel 4. Rata-Rata Nilai Indeks Vigor (\%) Benih Terung Kadaluarsa akibat Interaksi antara Konsentrasi Ekstrak Buah Tomat dan Spesies Trichoderma spp.

\begin{tabular}{cccc}
\hline \multirow{2}{*}{$\begin{array}{c}\text { Konsentrasi Ekstrak Buah } \\
\text { Tomat }\end{array}$} & \multicolumn{3}{c}{ Spesies Trichoderma spp. } \\
\cline { 2 - 4 } & Tanpa Trichoderma & Trichoderma & Trichoderma \\
spp. $\left(\mathrm{T}_{0}\right)$ & 26,67 & 57,33 & 28,00 \\
harzianum $\left(\mathrm{T}_{1}\right)$ & asperellum $\left(\mathrm{T}_{2}\right)$ \\
\hline \multirow{2}{*}{$0 \%\left(\mathrm{~K}_{0}\right)$} & $(30,99) \mathrm{bc}$ & $(49,24) \mathrm{f}$ & $(31,79) \mathrm{c}$ \\
& 17,33 & 58,67 & 30,67 \\
$10 \%\left(\mathrm{~K}_{1}\right)$ & $(24,57) \mathrm{b}$ & $(50,02) \mathrm{f}$ & $(33,55) \mathrm{cd}$ \\
& 6,67 & 53,33 & 26,67 \\
$15 \%\left(\mathrm{~K}_{2}\right)$ & $(14,80) \mathrm{a}$ & $(46,92) \mathrm{ef}$ & $(30,99) \mathrm{bc}$ \\
& 32,00 & 41,33 & 9,33 \\
$20 \%\left(\mathrm{~K}_{3}\right)$ & $(34,34) \mathrm{cd}$ & $(39,99) \mathrm{de}$ & $(17,36) \mathrm{a}$ \\
\hline
\end{tabular}

Perlakuan Biopriming Kombinasi Ekstrak Tomat dan Speies Trichoderma spp. terhadap Viabilitas dan Vigor Benih Terung (Solanum melongena L.) Kadaluarsa. 
Keterangan : -Angka yang Diikuti oleh Huruf yang Sama Berbeda Tidak Nyata pada Taraf 0,05 (Uji DMRT) -() Data setelah Ditransformasi

\section{c. Keserempakan Tumbuh (\%)}

Rerata nilai keserempakan tumbuh $\left(\mathrm{K}_{\mathrm{ST}}\right)$ benih terung kadaluarsa akibat interaksi antara konsentrasi ekstrak buah tomat dan spesies Trichoderma spp. dapat dilihat pada Tabel 5.

Tabel 5. Rata-Rata Nilai Keserempakan Tumbuh (\%) Benih Terung Kadaluarsa akibat Interaksi antara Konsentrasi Ekstrak Buah Tomat dan Spesies Trichoderma spp.

\begin{tabular}{cccc}
\hline \multirow{2}{*}{$\begin{array}{c}\text { Konsentrasi Ekstrak Buah } \\
\text { Tomat }\end{array}$} & \multicolumn{3}{c}{ Spesies Trichoderma spp. } \\
\cline { 2 - 4 } & $\begin{array}{c}\text { Tanpa Trichoderma } \\
\text { spp. }\left(\mathrm{T}_{0}\right)\end{array}$ & $\begin{array}{c}\text { Trichoderma } \\
\text { harzianum }\left(\mathrm{T}_{1}\right)\end{array}$ & $\begin{array}{c}\text { Trichoderma } \\
\text { asperellum }\left(\mathrm{T}_{2}\right)\end{array}$ \\
\hline \multirow{2}{*}{$0 \%\left(\mathrm{~K}_{0}\right)$} & 46,67 & 60,00 & 42,67 \\
& $(43,08) \mathrm{cde}$ & $(50,88) \mathrm{def}$ & $(40,72) \mathrm{bc}$ \\
$10 \%\left(\mathrm{~K}_{1}\right)$ & 30,67 & 73,33 & 44,00 \\
& $(33,62) \mathrm{ab}$ & $(59,20) \mathrm{f}$ & $(41,48) \mathrm{bcd}$ \\
$15 \%\left(\mathrm{~K}_{2}\right)$ & 18,67 & 66,67 & 40,00 \\
& $(25,47) \mathrm{a}$ & $(54,79) \mathrm{f}$ & $(39,18) \mathrm{bc}$ \\
$20 \%\left(\mathrm{~K}_{3}\right)$ & 41,33 & 62,67 & 36,00 \\
& $(39,99) \mathrm{bc}$ & $(52,55) \mathrm{ef}$ & $(36,85) \mathrm{bc}$ \\
\hline
\end{tabular}

Keterangan : -Angka yang Diikuti oleh Huruf yang Sama Berbeda Tidak Nyata pada Taraf 0,05 (Uji DMRT) -() Data setelah Ditransformasi

\section{d. Kecepatan Tumbuh (\%/etmal)}

Rerata nilai kecepatan tumbuh $\left(\mathrm{K}_{\mathrm{CT}}\right)$ benih terung kadaluarsa akibat interaksi antara konsentrasi ekstrak buah tomat dan spesies Trichoderma spp. dapat dilihat pada Tabel 6.

Tabel 6. Rata-Rata Nilai Kecepatan Tumbuh (\%/etmal) Benih Terung Kadaluarsa akibat Interaksi antara Konsentrasi Ekstrak Buah tomat dan Spesies Trichoderma spp.

\begin{tabular}{|c|c|c|c|}
\hline \multirow[b]{2}{*}{$\begin{array}{c}\text { Konsentrasi Ekstrak } \\
\text { Buah tomat }\end{array}$} & \multicolumn{3}{|c|}{ Spesies Trichoderma spp. } \\
\hline & $\begin{array}{c}\text { Tanpa Trichoderma } \\
\text { spp. }\left(\mathrm{T}_{0}\right)\end{array}$ & $\begin{array}{c}\text { Trichoderma } \\
\text { harzianum }\left(\mathrm{T}_{1}\right)\end{array}$ & $\begin{array}{l}\text { Trichoderma asperellum } \\
\left(\mathrm{T}_{2}\right)\end{array}$ \\
\hline \multirow{2}{*}{$0 \%\left(\mathrm{~K}_{0}\right)$} & 7,06 & 9,25 & 7,44 \\
\hline & $(15,33) \mathrm{bc}$ & $(17,62)$ cde & $(15,80) \mathrm{bc}$ \\
\hline \multirow{2}{*}{$10 \%\left(\mathrm{~K}_{1}\right)$} & 5,87 & 11,97 & 7,82 \\
\hline & $(14,02) b c$ & $(20,21) \mathrm{e}$ & $(16,20) b c$ \\
\hline \multirow{2}{*}{$15 \%\left(\mathrm{~K}_{2}\right)$} & 3,71 & 10,66 & 7,26 \\
\hline & $(11,10) \mathrm{a}$ & $(19,40)$ de & $(15,61) b c$ \\
\hline \multirow{2}{*}{$20 \%\left(\mathrm{~K}_{3}\right)$} & 7,28 & 9,18 & 5,78 \\
\hline & $(15,65) \mathrm{bc}$ & $(17,56) \mathrm{cd}$ & $(13,91) \mathrm{b}$ \\
\hline
\end{tabular}

Keterangan : -Angka yang Diikuti oleh Huruf yang Sama Berbeda Tidak Nyata pada Taraf 0,05 (Uji DMRT) -() Data setelah Ditransformasi

\section{e. Lama Waktu yang Dibutuhkan untuk Mencapai 50\% Perkecambahan Normal Relatif (hari)}

Rerata nilai lama waktu yang dibutuhkan untuk mencapai $50 \%$ perkecambahan normal relatif $\left(\mathrm{T}_{50}\right)$ benih terung kadaluarsa akibat interaksi antara konsentrasi ekstrak buah tomat dan spesies Trichoderma spp. dapat dilihat pada Tabel 7. 
Tabel 7. Rata-Rata Nilai Lama Waktu yang Dibutuhkan untuk Mencapai 50\% Perkecambahan Normal Relatif (hari) Benih Terung Kadaluarsa akibat Interaksi antara Konsentrasi Ekstrak Buah tomat dan Spesies Trichoderma spp.

\begin{tabular}{cccc}
\hline \multirow{2}{*}{$\begin{array}{c}\text { Konsentrasi Ekstrak Buah } \\
\text { Tomat }\end{array}$} & \multicolumn{3}{c}{ Spesies Trichoderma spp. } \\
\cline { 2 - 4 } & $\begin{array}{c}\text { Tanpa Trichoderma } \\
\text { spp. }\left(\mathrm{T}_{0}\right)\end{array}$ & $\begin{array}{c}\text { Trichoderma } \\
\text { harzianum }\left(\mathrm{T}_{1}\right)\end{array}$ & $\begin{array}{c}\text { Trichoderma } \\
\text { asperellum }\left(\mathrm{T}_{2}\right)\end{array}$ \\
\hline $0 \%\left(\mathrm{~K}_{0}\right)$ & $9,09 \mathrm{bc}$ & $8,52 \mathrm{c}$ & $7,58 \mathrm{c}$ \\
$10 \%\left(\mathrm{~K}_{1}\right)$ & $8,11 \mathrm{c}$ & $6,95 \mathrm{c}$ & $7,41 \mathrm{c}$ \\
$15 \%\left(\mathrm{~K}_{2}\right)$ & $13,36 \mathrm{a}$ & $6,83 \mathrm{c}$ & $8,55 \mathrm{c}$ \\
$20 \%\left(\mathrm{~K}_{3}\right)$ & $8,30 \mathrm{c}$ & $6,72 \mathrm{c}$ & $11,49 \mathrm{ab}$ \\
\hline
\end{tabular}

Keterangan : Angka yang Diikuti oleh Huruf yang Sama Berbeda Tidak Nyata pada Taraf 0,05 (Uji DMRT)

Pada peubah potensi tumbuh maksimum, indeks vigor, keserempakan tumbuh, kecepatan tumbuh dan lama waktu yang dibutuhkan untuk mencapai $50 \%$ perkecambahan normal relatif nilai terbaik diperoleh pada perlakuan kombinasi konsentrasi ekstrak buah tomat $10 \%$ dengan spesies $T$. harzianum. Hal ini disebabkan karena terdapat berbagai kandungan senyawa organik di dalam ekstrak tomat seperti karbohidrat, asam amino dan hormon tumbuh seperti Indole Acetic Acid (IAA), 2,4-D dan Indole Butyric Acid (IBA) (Marliah et al., 2010). Trichoderma spp. diketahui sebagai salah satu jenis mikroba tanah yang selain berfungsi sebagai agen biokontrol tetapi juga memiliki peran dalam memacu pertumbuhan tanaman (Harman et al., 2004).

Pada beberapa spesies Trichoderma spp. termasuk jenis T. harzianum dan T. asperellum akan berkoloni dan tumbuh berasosiasi dengan perakaran tanaman kemudian akan menghasilkan fitohormon seperti IAA dan hormon sejenisnya yang mampu memperbaiki pertumbuhan tanaman (Vinale et al., 2008). Wanjiru (2009) juga menyatakan bahwa spesies T. harzianum telah diketahui memproduksi ZPT yaitu IAA yang merupakan jenis hormon auksin yang dapat memacu pertumbuhan tanaman dengan meningkatkan laju pertumbuhan akar, seperti perpanjangan akar primer serta perbanyakan akar lateral dan akar adventif, yang merupakan suatu keuntungan bagi kecambah dalam meningkatkan kemampuannya untuk lebih merekatkan diri ke tanah, menyerap air, serta nutrisi dari lingkungan sehingga tanaman tersebut akan tumbuh lebih baik. Charisma et al. (2012) juga menyatakan hal serupa bahwa selain sebagai organisme pengurai dan agen hayati, $T$. harzianum juga menjadi stimulator pertumbuhan tanaman dengan menghasilkan hormon IAA yang termasuk kedalam golongan auksin dan bekerja dengan memacu pemanjangan akar dan pertumbuhan tunas.

Mekanisme kerja Trichoderma spp. dapat mempengaruhi peningkatan pertumbuhan tanaman seperti dapat menghasilkan zat pengatur tumbuh, dapat mempercepat proses pelarutan nutrisi yang sulit dilarutkan di dalam tanah dan peningkatan penyerapan dan pengangkutan mineral-mineral yang sulit tersedia. Peningkatan pertumbuhan serta hasil tanaman berdasarkan peran dari Trichoderma spp. disebabkan oleh meluasnya area perakaran yang dapat memperluas volume akar untuk mengakses nutrisi dari tanah dan meningkatkan proses pelarutan zat-zat yang sukar larut bahkan dapat menyediakan ketersediaan mikronutriens (Akbari et al., 2007).

\section{Pengaruh spesies Trichoderma terhadap Daya Berkecambah (\%) Benih Terung Kadaluarsa}

Rerata nilai daya berkecambah (DB) benih terung kadaluarsa akibat perlakuan spesies Trichoderma dapat dilihat pada Tabel 8. 
Tabel 8. Rata-Rata Nilai Daya Berkecambah (\%) Benih Terung Kadaluarsa akibat Perlakuan Spesies Trichoderma spp.

Spesies Trichoderma Daya Berkecambah (\%)

\begin{tabular}{lc}
\hline Spesies Trichoderma & Daya Berkecambah $(\%)$ \\
\hline Tanpa Trichoderma $\left(\mathrm{T}_{0}\right)$ & 47,33 \\
& $(43,45) \mathrm{a}$ \\
Trichoderma harzianum $\left(\mathrm{T}_{1}\right)$ & 68,67 \\
& $(56,37) \mathrm{c}$ \\
Trichoderma asperellum $\left(\mathrm{T}_{2}\right)$ & 56,00 \\
\end{tabular}

Keterangan : -Angka yang Diikuti oleh Huruf yang Sama Berbeda Tidak Nyata pada Taraf 0,05 (Uji DMRT)

-() Data setelah Ditransformasi

Pada peubah daya berkecambah nilai terbaik diperoleh pada perlakuan T. harzianum. Nilai daya berkecambah yang diperoleh pada perlakuan T. harzianum secara nyata lebih tinggi dibanding spesies $T$. asperellum. Hal ini diduga berhubungan dengan kemampuan Trichoderma dalam memproduksi IAA. Diketahui bahwa IAA termasuk kedalam golongan auksin dimana hormon ini mendukung pertumbuhan tanaman dengan memacu pemanjangan sel, merangsang pembentukan akar baru, merangsang pembungaan dan meningkatkan aktivitas enzim (Arshad dan Frankenberger, 1993). Diduga spesies T. harzianum memproduksi hormon IAA yang lebih tinggi dibanding $T$. asperellum sehingga dapat mendukung proses perkecambahan yang lebih baik. Maulidia (2014) juga mengatakan bahwa kemungkinan besar spesies $T$. harzianum memproduksi IAA lebih tinggi dibanding $T$. asperellum karena perlakuan benih menggunakan T. harzianum pada konsentrasi air kelapa muda $15 \%$ sudah mampu meningkatkan viabilitas dan vigor benih. Sementara pada $T$. asperellum nilai viabilitas dan vigor benih yang tinggi diperoleh pada konsentrasi air kelapa muda $20 \%$.

\section{KESIMPULAN}

Terjadi interaksi yang nyata akibat perbedaan jenis Trichoderma dan konsentrasi ekstrak buah tomat pada semua peubah yang diamati kecuali daya berkecambah. Perubahan nilai pada suatu peubah akibat peningkatan konsentrasi ekstrak buah tomat tergantung pada jenis Trichoderma spp. yang digunakan. Konsentrasi ekstrak buah tomat terbaik untuk meningkatkan viabilitas dan vigor benih terung kadaluarsa dijumpai pada konsentrasi ekstrak buah tomat $10 \%$, baik yang dikombinasikan dengan T. harzianum maupun $T$. asperellum. Jenis Trichoderma spp. terbaik untuk meningkatkan viabilitas dan vigor benih terung kadaluarsa dijumpai pada $T$. harzianum pada semua konsentrasi ekstrak buah tomat. Kombinasi terbaik untuk meningkatkan viabilitas dan vigor benih terung kadaluarsa dijumpai pada kombinasi perlakuan konsentrasi ekstrak buah tomat $10 \%$ dengan T. harzianum. Pada peubah daya berkecambah terjadi peningkatan nilai sebesar $22,62 \%$.

\section{DAFTAR PUSTAKA}

Akbari, G., A.S.M.H. Arab, A. Alikhani, I. Allahdadi dan M.H. Arzanes. 2007. Isolation and selection of indigenous Azospirillum spp. and IAA of superior strain on wheat roots. World J. of Agricultural Sci. 3: 523-529.

Arshad, M. dan W.T. Frankenberger. 1993. Microbial production of plant growth regulators. Soil Microbial Ecology. Marcel Dekker, Inc. New York-Bassel-Hongkong p. 307-347. 
Badan Pusat Statistik dan Direktorat Jendral Hortikultura. 2016. Produktivitas Sayuran di Indonesia 2011-2015. Http://www.pertanian.go.id/Data5tahun/pdf HORTI2016/3 Produktivitas\%20\%20Nasional\%20Sayuran.pdf. [Diakses 12 Juni 2017]

Bjorkman, T., L.M. Blancgard dan G.E. Harman. 1999. Solubilization of phosphates and miconutrients by the plant-growth-promoting and biocontrol fungus Trichoderma harzianum 1295-22: effect of environmental stress. J. Amer. Soc. Hort. Sci. 123 (1): 35-40.

Charisma, A. M., S.R. Yuni dan Isnawati. 2012. Pengaruh kombinasi kompos Trichoderma dan Mikoriza Vesikular Arbuskular (MVA) terhadap pertumbuhan tanaman kedelai (Glycine max (L.) Merill) pada media tanam tanah kapur. J. LenteraBio. $1(3)$ : 111-116.

Harman G.E., C.R. Howell, A. Viterbo dan M. Lorito. 2004. Trichoderma species opportunistic, avirulent plant symbionts. Nature Reviews in Microbiology. 2: 43-56.

Marliah, A., M. Nasution., dan S. Azmi. 2010. Pengaruh masa kadaluarsa dan penggunaan berbagai ekstrak bahan organik terhadap viabilitas dan vigor benih semangka (Citrullus vulgaris Schard.). J. Agrista. 14 (2): 44-50.

Maulidia, V. 2014. Perlakuan biopriming kombinasi air kelapa dan Trichoderma terhadap viabilitas dan vigor benih cabai kadaluarsa (Capsicum annum L.). Skripsi. Program Studi Agroteknologi. Fakultas Pertanian. Universitas Syiah Kuala, Banda Aceh.

Sunarjono, H. 2013. Bertanam 36 Jenis Sayur. Penebar Swadaya, Jakarta.

Sutopo, L. 2002. Teknologi Benih. RajaGrafindo Persada, Jakarta.

Vinale, F., K. Sivasithamparam, E.L. Ghisalberti, R. Marra, M.J. Barbetti, H. Li, S.L. Woo dan M. Lorito. 2008. A novel role for Trichoderma secondary metabolites in the interactions with plants. Physiol Mol Plant Pathol. 72: 80-86.

Wanjiru, M.M. 2009. Effect of Trichoderma harzianum and Arbuscular mycorrhizal fungi on growth of tea cuttings, napier grass and disease management in tomato seedlings. Plant and Microbial Sciences. 13: 305-312. 